\title{
PENGARUH PENGUNGKAPAN CORPORATE SOCIAL RESPONSIBILITY DAN LEVERAGE TERHADAP HARGA SAHAM: PROFITABILITAS SEBAGAI PEMODERASI
}

\author{
Anak Agung Dewi Hendrayani ${ }^{1}$ \\ Ni Luh Putu Wiagustini ${ }^{2}$ \\ Ida Bagus Panji Sedana ${ }^{3}$ \\ $\begin{aligned} & 1 \text { Fakultas Ekonomi dan Bisnis Universitas Udayana, Bali, Indonesia } \\ & { }^{1} \text { Email: dewihendrayani112@ yahoo.co.id }\end{aligned}$
${ }^{2}$ Fakultas Ekonomi dan Bisnis Universitas Udayana, Bali, Indonesia
${ }^{3}$ Fakultas Ekonomi dan Bisnis Universitas Udayana, Bali, Indonesia
}

\begin{abstract}
ABSTRAK
Tujuan dari penelitian ini adalah untuk mengetahui hubungan antara Corporate Social Responsibility dan leverage terhadap harga saham. Hubungan antara Corporate Social Responsibility dan leverage terhadap harga saham dianalisis menggunakan profitabilitas sebagai pemoderasi. Sampel data penelitian yang digunakan adalah perusahaan manufaktur. Rasio perhitungan Corporate Social Responsibility dihitung menggunakan data Global Reporting Invitiate (GRI). Rasio leverage yang dihitung adalah nilai debt to equity ratio (DER). Rasio profitabilitas yang dihitung adalah rasio Return on Equity (ROE). Data harga saham yang digunakan adalah harga saham yang ditentukan melalui closing price. Analisis data dilakukan menggunakan metode analisis Moderated Regression Analysis (MRA). Data diolah menggunakan software Statistical Package for Social Science. Hasil analisis menunjukkan bahwa Corporate Social Responsibility dan leverage tidak berpengaruh secara signifikan terhadap harga saham. Profitabilitas berpengaruh secara signifikan terhadap harga saham. Profitabilitas secara signifikan mampu memoderasi hubungan antara Corporate Social Responsibility dan leverage terhadap harga saham.
\end{abstract}

Kata Kunci: Corporate Social Responsibility, leverage, profitabilitas, dan harga saham

\begin{abstract}
The porpuse of this study is to determine the relationship between Corporate Social Responsibility and leverage on stock price. The relationship between Corporate Social Responsibility and leverage on stock price were analyzed using profitability as a moderating. This study was used data from manufacturing companies. Corporate Social Responsibility was counted using Global Reporting Invitiate (GRI) data. Leverage was calculated ratio the value of the debt to equity ratio (DER). Profitability ratio counted was Return on Equity (ROE). The stock price data was used the stock price determined by the closing price. Data analysis was conducted using the method of analysis Moderated Regression Analysis (MRA). The data were analysis using computer software Statistical Package for Social Science. The results showed that Corporate Social Responsibility and Leverage was not a significant effect on stock price. Profitability was significantly influenced stock price. Profitability was significantly able to moderate the relationship between Corporate Social Responsibility and leverage with stock price.
\end{abstract}

Keywords: Corporate Social Responsibility, leverage, profitability, and stock price. 


\section{PENDAHULUAN}

Nilai perusahaan menggambarkan pandangan investor pada tingkat keberhasilan dari suatu perusahaan yang tercermin dari harga saham. Seorang investor tentunya mengharapkan adanya return yang maksimal dengan saham yang diinvestasi. Semakin meningkat harga saham suatu perusahaan, maka akan semakin meningkat juga kemakmuran para pemegang saham (Nurlela dan Islahuddin, 2008). Semakin banyak investor yang tertarik berinvestasi maka semakin meningkatlah nilai perusahaan (Mukhtaruddin et al., 2014). Beberapa kebijakan dapat perusahaan laksanakan untuk menjaga harga saham. Penggunaan leverage dan pelaksanaan Corporate Social Responsibility menjadi salah satu kebijakan dasar untuk menjaga harga saham.

Penggunaan leverage adalah salah satu kebijakan yang perusahaan dapat lakukan untuk meningkatkan harga saham. Leverage menggambarkan tingkat penggunaan hutang yang digunakan perusahaan dalam proses pendanaan seluruh aktivitasnya. Pendanaan seluruh aktivitas disini termasuk didalamnya adalah proses produksi. Tingkat produksi yang tinggi diharapakan dapat meningkatkan tingkat profit perusahaan. Oleh karena itu penggunaan hutang yang tinggi harusnya dapat memberikan perubahan harga saham yang lebih tinggi (Rusliati dan Prasetyo, 2011).

Rasio leverage yang tinggi menyebabkan para investor lebih mempertimbangkan keputusan investasinya. Rasio leverage yang tinggi dianggap sebagai suatu risiko yang dihindari oleh investor (Rusliati dan Prasetyo, 2011). Penggunaan leverage harus diimbangi dengan profit yang tinggi untuk 
menghasilkan harga saham yang tinggi juga. Semakin tinggi profit maka para investor akan semakin berminat untuk berinvestasi pada suatu saham. Manfaat dari kebijakan leverage yang perusahaan ambil akan berdampak baik jika kebijakan tersebut dilakukan dengan menghasilkan profit yang seimbang.

Beberapa penelitian membahas hubungan antara leverage dan harga saham. Rusliati dan Prasetyo (2011) menyatakan financial leverage tidak berpengaruh dengan harga saham. Hasil analisis Wilianto (2012), Luhukay, dkk (2016), dan Ariyanti, dkk (2016) juga menunjukkan hal yang sejalan. Berbeda dengan Mahmud (2014) dan Kusumawardani (2010) yang menyatakan bahwa leverage berpengaruh terhadap harga saham.

Pelaksanaan Corporate Social Responsibility ialah kebijakan yang perusahaan dapat lakukan untuk meningkatkan harga saham. Berdasarkan UndangUndang Nomor 40 Tahun 2007 menyatakan Corporate Social Responsibility tidak lagi hal yang dilakukan secara sukarela tetapi merupakan suatu hal yang patut dipertanggungjawabkan dari dampak yang perusahaan lakukan. Kebijakan pelaksanaan Corporate Social Responsibility sudah ditetapkan dan ditegaskan dalam sebuah undang-undang. Setiap perusahaan harus melaksanakan Corporate Social Responsibility secara wajib untuk menjaga dan mempertanggungjawabkan dampak-dampak yang dihasilkan dari aktivitasnya.

Corporate Social Responsibility suatu perusahaan dapat terjadi antara seluruh elemen perusahaan dengan seluruh stakeholder (Kiran et al., 2015). Kondisi yang menggambarkan hubungan perusahaan dengan semua stakeholder menyebabkan Corporate Social Responsibility tidak berpijak secara single bottom 
line. Jadi sebelumnya pelaksanaan Corporate Social Responsibility hanya mengacu pada elemen perusahaan itu sendiri saja. Babalola (2012) menyatakan bahwa teori Corporate Social Responsibility diartikan sebagai konsep triple bottom line yaitu people, planet, dan profit. Berdasarkan pada konsep tersebut maka perusahaan bertanggung jawab atas seluruh aktivitas sosial, lingkungan dan tidak hanya pada laba yang dihasilkan.

Corporate Social Responsibility memiliki hubungan erat dengan pembangunan berkelanjutan. Pelaksanaan Corporate Social Responsibility harus dilakukan secara rutin untuk dapat menciptakan pembangunan yang berkelanjutan. Pelaksanaan program Corporate Social Responsibility terjadi dikarenakan perusahaan tidak hanya memperhatikan profit melainkan citra perusahaan dimata berbagai stakeholder (Carrol dan Shabana, 2010). Corporate Social Responsibility merupakan strategi yang digunakan untuk meningkatkan citra perusahaan yang didasarkan pada impression management theory.

Penelitian terdahulu menyatakan hubungan antara Corporate Social Responsibility dan harga saham. Hasil penelitian Hidayansyah, dkk (2015) menyebutkan bahwa Corporate Social Responsibility berpengaruh tidak signifikan dengan harga saham. Hasil penelitian Putri (2013) dan Anwar dkk. (2010) menunjukkan hasil bahwa Corporate Social Responsibility berpengaruh signifikan dengan harga saham. Penelitian Pratomo (2010) menyatakan secara simultan pengungkapan informasi Corporate Social Responsibility berpengaruh signifikan dengan harga saham. Pengaruh positif Corporate Social Responsibility dengan 
harga saham dapat disebabkan karena para investor mulai mempertimbangkan aspek-aspek sosial dalam proses investasi Hamdani (2014).

Profitabilitas dapat menggambarkan suatu pengembalian dari investasi keuangan. Boaventura et al. (2012) menyatakan bahwa suatu perusahaan memiliki tujuan untuk mencapai profit yang maksimum. Pencapaian profit yang maksimum oleh suatu perusahaan dianggap sebagai suatu keberhasilan yang dapat perusahaan capai. Jika perusahaan memiliki kemampuan untuk mengoptimalkan profitabilitasnya, maka profit yang optimal dapat meningkatkan minat para investor untuk berinvestasi. Semakin baik suatu perusahaan dapat menciptakan profitnya maka akan semakin banyak investor yang mempertimbangkan perusahaan tersebut.

Pentingnya profit untuk meningkatkan minat para investor untuk berinvestasi menggambarkan pentingnya tingkat profitabilitas pada suatu perusahaan sehingga dapat ditetapkan sebagai variabel moderasi. Pelaksanaan Corporate Social Responsibility tidak dapat dilakukan jika suatu perusahaan tidak mendapatkan profit yang seimbang. Pelaksanaan kebijakan hutang tanpa diimbangi dengan profit yang tinggi dapat memunculkan risiko dipihak para investor. Risiko kebijakan hutang tentunya dapat mempengaruhi harga saham, sehingga diperlukan profit yang seimbang untuk bisa melakukan kebijakan kebijakan hutang. Tindakan positif juga diperlukan agar perusahaan dapat meningkatkan dan mempertahankan tingkat profitabilitasnya.

Profitabilitas sebagai pemoderasi memiliki hubungan terhadap harga saham, Corporate Social Responsibility, dan leverage. Polli, dkk (2014) menyatakan bahwa ROE berpengaruh signifikan terhadap harga saham. Pengaruh 
signifikan menandakan peningkatan laba pada perusahaan dapat mempengaruhi harga saham perusahaan Sondakh, dkk (2015). Manoppo (2015) dan Rinati (2009) juga melakukan penelitian dengan menguji pengaruh rasio ROE dengan harga saham. Hasil penelitiannya menunjukkan pengaruh positif signifikan.

Hubungan antara Corporate Social Responsibility terhadap profitabilitas juga dibahas melalui beberapa hasil penelitian. Iqbal et al. (2012) menemukan hasil bahwa Corporate Social Responsibility pengaruh tidak signifikan dengan kinerja keuangan. Pengaruh tersebut dapat dikarenakan oleh beberapa faktor salah satunya adalah rasio pengungkapan Corporate Social Responsibility yang kecil pada perusahaan sampel. Faktor lainnya dapat disebabkan oleh memang secara murni pelaksanaan Corporate Social Responsibility tidak memberikan dampak apapun terhadap kinerja keuangan. Lech (2013), Rosiliana dkk. (2014), dan Yaparto dkk. (2013) juga menyatakan hal yang sejalan.

Kanwal et al. (2013) menyatakan Corporate Social Responsibility memiliki pengaruh terhadap kinerja keuangan. Ketika perusahaan melakukan tanggung jawabnya melalui program Corporate Social Responsibility terciptalah citra baik dibenak pelanggan, pemasok, maupun investor. Penelitian Lee dan Park (2010) dan Peloza (2009) juga menyatakan bahwa terjadi pengaruh positif antara kinerja keuangan dengan pelaksanaan Corporate Social Responsibility baik secara sosial dan lingkungan.

Penelitian Edmawati (2012) dan Handriyani (2013) menyatakan bahwa profitabilitas tidak secara signifikan mampu memoderasi hubungan Corporate Social Responsibility dan nilai perusahaan. Semakin tinggi profit yang diperoleh 
perusahaan, semakin besar pengungkapan Corporate Social Responsibility (Anggraini, 2006). Salah satu indikator penting dalam nilai perusahaan adalah ditentukan melalui harga saham.

Beberapa penelitian juga membahas hubungan antara leverage terhadap profitabilitas. Amirya dan Atmini (2008) dengan perspektif pecking order theory menunjukkan adanya pengaruh negatif antara profitabilitas dan tingkat hutang. Hasil yang sama juga terjadi pada penelitian Tahalele dan Mekel (2014), karena rasio leverage tidak memiliki efek yang cukup kuat untuk mempengaruhi profitabilitas pada perusahaan. Putriana (2016) melakukan penelitian dengan menguji pengaruh profitabilitas (ROE) dalam memoderasi hubungan leverage (DER) terhadap harga saham. Hasil penelitian menyatakan bahwa ROE mampu memoderasi hubungan DER terhadap harga saham.

Berdasarkan pada hasil penelitian-penelitian yang sudah dijelaskan sebelumnya, maka dilakukan pengujian data di perusahaan manufaktur. Pemilihan sampel pada perusahaan tersebut karena dianggap sebagai perusahaan yang berpengaruh pada perkembangan ekonomi. Kondisi perusahaan manufaktur berlaku jika ditinjau dari segi internal dan eksternal perusahaan. Perusahaan manufaktur juga sering dikaitkan dengan masyarakat dan lingkungan karena tingkat konsumsi yang lebih tinggi jika dibandingkan dengan sektor lainnya.

Penggunaan variabel moderasi yaitu profitabilitas bertujuan untuk mengetahui kedudukannya dapat memperkuat atau memperlemah hubungan antar variabel. Perusahaan akan menggunakan sebagian keuntungannya untuk pelaksanaan aksi sosial seperti halnya penerapan Corporate Social Responsibility. 
AA Dewi Hendrayani, Ni Luh Putu Wiagustini, dan I B Panji Sedana. Pengaruh Pengungkapan.....

Semakin baik citra yang dihasilkan melalui penerapan Corporate Social Responsibility maka semakin baik pengaruh yang diberikan terhadap harga saham.

Fenomena yang terjadi antara leverage dan harga saham yaitu semakin tinggi penggunaan leverage yang diimbangi dengan profit yang tinggi, maka cenderung dapat meningkatkan harga saham. Berkaitan dengan ekuitas yang dimiliki perusahaan maka perhitungan variabel profitabilitas akan diukur dengan menggunakan rasio ROE. Perhitungan rasio ROE dilakukan karena ROE merupakan rasio modal perusahaan. Semakin tinggi rasio ROE maka semakin tinggi keuntungan perusahaan (Agustina, 2013).

Pada penelitian ini diharapkan pelaksanaan Corporate Social Responsibility dan leverage dapat meningkatkan harga saham dengan profitabilitas sebagai pemoderasi. Meningkatnya harga saham diharapkan dapat menjaga eksistensi perusahaan di lingkungan internal maupun eksternal. Suatu perusahaan juga dapat mempertimbangkan strategi pengungkapan Corporate Social Responsibility serta aspek lainnya yakni leverage dan profitabilitas dalam kebijakan perusahaan.

Uraian mengenai latar belakang penelitian menghasilkan berbagai permasalahan yang dibahas pada penelitian ini. Berdasarkan pada penelitianpenelitian sebelumnya dan teori-teori pendukungnya, maka dilakukan pengujian berdasarkan pokok permasalahan yang ditemukan. Pokok permasalahan dalam penelitian ini adalah:

1) Bagaimana signifikansi Corporate Social Responsibility, leverage, dan profitabilitas terhadap harga saham? 
2) Apakah profitabilitas secara signifikan dapat memoderasi Corporate Social Responsibility dan leverage terhadap harga saham?

Menjawab dari pokok permasalahan yang sudah ditetapkan maka tersusunlah tujuan penelitian ini. Tujuan penelitian menjelaskan inti dari hasil penelitian ini. Tujuan dalam penelitian ini adalah:

1) Menganalisis signifikansi pengaruh Corporate Social Responsibility, leverage, dan profitabilitas terhadap harga saham.

2) Menganalisis apakah profitabilitas secara signifikan dapat memoderasi Corporate Social Responsibility dan leverage terhadap harga saham.

Setelah menetapkan latar belakang masalah dan tujuan, langkah selanjutnya adalah penentuan hipotesis. Berdasarkan pada latar belakang yang disusun dari penelitian-penelitian sebelumnya dan teori-teori pendukungnya serta pada permasalahan yang ditemukan, maka ditentukan hipotesis sebagai berikut:

$\mathrm{H}_{1}=$ Pengungkapan Corporate Social Responsibility berpengaruh signifikan terhadap harga saham

$\mathrm{H}_{2}=$ Leverage berpengaruh signifikan terhadap harga saham

$\mathrm{H}_{3}=$ Profitabilitas berpengaruh signifikan terhadap harga saham

$\mathrm{H}_{4}=$ Profitabilitas secara signifikan mampu memoderasi Corporate Social Responsibility terhadap harga saham

$\mathrm{H}_{5}=$ Profitabilitas secara signifikan mampu memoderasi leverage terhadap harga saham

\section{METODE PENELITIAN}


AA Dewi Hendrayani, Ni Luh Putu Wiagustini, dan I B Panji Sedana. Pengaruh Pengungkapan.....

Rancangan penelitian ini merupakan penelitian kausalitas, yaitu melakukan pengujian hipotesis. Beberapa ruang lingkup yang akan ditentukan yaitu:

1) Penelitian ini menggunakan data Global Reporting Invitiate (GRI) sebagai acuan dalam proses pengukuran pengungkapan Corporate Social Responsibility. Jumlah item yang akan diukur adalah sebanyak 79 item.

2) Penelitian ini menggunakan rasio leverage yang dapat diukur melalui nilai Debt to Equity Ratio (DER), rasio ini diperoleh dari total hutang dibagi dengan total ekuitas.

3) Penelitian ini menggunakan harga saham yang ditentukan melalui closing price.

4) Penelitian ini menggunakan rasio profitabilitas yang dapat diukur melalui rasio Return On Equity (ROE). Rasio ini merupakan profit yang dihasilkan setelah pajak terhadap total ekuitas.

5) Perusahaan yang digunakan sebagai objek penelitian adalah hanya perusahaan dari saham manufaktur di BEI tahun 2015.

Variabel yang akan diteliti adalah variabel independen, dependen, dan moderasi. Corporate Social Responsibility dianalisis menggunakan Corporate Social Disclosure Index (CSDI). Penghitungan CSDI menggunakan variabel dummy, setiap indeks Corporate Social Responsibility diberi nilai 1 bila mengungkapkan, dan nilai 0 bila tidak mengungkapkan (Rosiliana dkk., 2014).

$$
\mathrm{CSDIj}=\frac{\sum \mathrm{Xij}}{\mathrm{nj}}
$$

Leverage ditentukan dari nilai Debt to Equity Ratio (DER). DER merupakan setiap modal sendiri yang digunakan sebagai jaminan hutang. Data hasil penelitian 
diharapkan dapat berkesinambungan antar variabel yang satu dengan yang lainnya. Perhitungan DER dapat menggunakan rumus:

$$
\text { DER }=\frac{\text { Total hutang }}{\text { Total ekuitas }}
$$

Profitabilitas pada penelitian ini diukur menggunakan rasio ROE. Pemilihan rasio ROE dilakukan karena penggunaan dana untuk proses pelaksanaan Corporate Social Responsibility cenderung berasal dari laba bersih setelah pajak. Kebijakan leverage juga didasarkan pada total ekuitas yang dimiliki perusahaan, maka penelitian ini digunakan perhitungan rasio ROE saja. Rumus perhitungannya sebagai berikut:

$$
\mathrm{ROE}=\frac{\text { Laba bersih setelah pajak }}{\text { Total Ekuitas }}
$$

Harga saham pada penelitian ini ditentukan melalui closing price per bulan yang dirata-ratakan menjadi closing price per tahun. Harga penutupan atau closing price merupakan harga akhir pada waktu penutupan yang terbentuk dari adanya permintaan dan penawaran. Harga saham diperoleh dari data masing-masing saham perusahaan yang digunakan sebagai sampel.

Sumber data populasi dan sampel menggunakan laporan tahunan dan keuangan perusahaan manufaktur di BEI tahun 2015. Metode pemilihan sampel yang dipakai adalah metode sensus. Metode sensus ditetapkan karena pada penelitian ini dilakukan penelitian pada semua populasi. Jadi seluruh perusahaan diteliti sesuai dengan kelengkapan data yang tersedia. Jumlah sampel yang dianalisis berjumlah 121 perusahaan.

\section{HASIL PENELITIAN DAN PEMBAHASAN}


Langkah awal yang dilakukan adalah melakukan uji asumsi klasik pada data-data yang dianalisis. Uji asumsi klasik memiliki empat bagian langkah uji. Rangkaian uji asumsi klasik terdiri dari uji normalitas, uji multikolinieritas, uji heteroskedastisitas, dan uji autokorelasi. Uji normalitas menggunakan metode Uji Kolmogorof Smirnov. Berdasarkan hasil output SPSS dapat diketahui bahwa nilai Asymp. Sig. (2-tailed) yaitu sebesar 0,059. Nilai tersebut menandakan bahwa pada model lebih besar dari 0,05 . Hasil analisis menyatakan bahwa data terdistribusi normal.

Uji multikolinieritas dilakukan untuk mengetahui apakah pada model ditemukan adanya korelasi antar variabel. Pengujian didasarkan pada nilai Tolerance dan Variance Inflation Factor (VIF).

Tabel 1.

Uji Multikolinieritas

\begin{tabular}{ccc}
\hline Model & Tolerance & VIF \\
\hline (Constant) & & \\
$\mathrm{X}_{1}$ & .966 & 1.036 \\
$\mathrm{X}_{2}$ & .965 & 1.036 \\
$\mathrm{Z}_{1}$ & .307 & 3.255 \\
$\mathrm{X}_{1} \mathrm{Z}_{1}$ & .984 & 1.016 \\
$\mathrm{X}_{2 .} \mathrm{Z}_{1}$ & .315 & 3.174 \\
\hline Sumber $:$ Data diolah, 2017 &
\end{tabular}

Sumber : Data diolah, 2017

Nilai tolerance di atas 0,1 dan nilai VIF di bawah 10, maka tidak terjadi masalah multikolinearitas. Pada Tabel 1. dapat dilihat bahwa seluruh hubungan antar variabel memiliki nilai yang sesuai dengan kriteria tidak terjadi masalah multikolinearitas. Berdasarkan hasil analisis data dinyatakan tidak terjadi multikolinearitas, yang artinya model uji baik.

Selanjutnya dilakukan uji heteroskedastisitas. Uji statistik yang dapat digunakan untuk menganalisis ada tidaknya heteroskedastisitas adalah Uji Glejser. Apabila signifikansi antar variabel independen dengan nilai absolut residual pada 
Uji Glejser diatas tingkat kepercayaan 0,05 maka data dinyatakan bebas dari Heteroskedastisitas.

Tabel 2.

Uji Heteroskedastisitas

\begin{tabular}{ccc}
\hline Model & $\mathbf{t}$ & Sig. \\
\hline (Constant) & 6.652 & .000 \\
$\mathrm{X}_{1}$ & 1.244 & .216 \\
$\mathrm{X}_{2}$ & .175 & .861 \\
$\mathrm{Z}_{1}$ & 1.364 & .175 \\
$\mathrm{X}_{1} \mathrm{Z}_{1}$ & -.023 & .982 \\
$\mathrm{X}_{2 .} \mathrm{Z}_{1}$ & -.195 & .846 \\
\hline Sumber $:$ Data diolah, 2017 &
\end{tabular}

Pada Tabel 2. dapat dilihat bahwa:

1) Pada hubungan Corporate Social Responsibility $\left(\mathrm{X}_{1}\right)$ dan harga saham $(\mathrm{Y})$, diperoleh nilai sebesar 0,216 . Berdasarkan pada kriteria uji, maka dinyatakan bahwa hubungan ini tidak terjadi heteroskedastisitas.

2) Pada hubungan leverage $\left(\mathrm{X}_{2}\right)$ dan harga saham $(\mathrm{Y})$, diperoleh nilai signifikansi sebesar 0,861. Berdasarkan pada kriteria uji, maka dinyatakan bahwa hubungan ini tidak terjadi heteroskedastisitas.

3) Pada hubungan profitabilitas $\left(\mathrm{Z}_{1}\right)$ dan harga saham (Y), diperoleh nilai signifikansi sebesar 0,175 . Berdasarkan pada kriteria uji, maka dinyatakan bahwa hubungan ini tidak terjadi heteroskedastisitas.

4) Pada hubungan interaksi antara Corporate Social Responsibility dengan profitabilitas $\left(\mathrm{X}_{1} \mathrm{Z}_{1}\right)$ dan harga saham $(\mathrm{Y})$, diperoleh nilai signifikansi sebesar 0,982. Berdasarkan pada kriteria uji, maka dinyatakan bahwa hubungan ini tidak terjadi heteroskedastisitas.

5) Pada hubungan interaksi antara leverage dengan profitabilitas $\left(\mathrm{X}_{2} \mathrm{Z}_{1}\right)$ dan harga saham (Y), diperoleh nilai signifikansi sebesar 0,846. Berdasarkan pada kriteria uji, maka dinyatakan bahwa hubungan ini tidak terjadi heteroskedastisitas. 
AA Dewi Hendrayani, Ni Luh Putu Wiagustini, dan I B Panji Sedana. Pengaruh Pengungkapan.....

Berdasarkan hasil analisis data dinyatakan semua data dinyatakan bebas dari heteroskedastisitas.

Uji autokorelasi dilakukan untuk mengetahui ada atau tidaknya korelasi antara kesalahan pengganggu pada periode saat ini dengan kesalahan pengganggu pada periode sebelumnya. Uji Durbin Watson (DW Test) dipakai untuk mendeteksi ada atau tidaknya autokorelasi. Berdasarkan hasil perhitungan Uji Durbin Watson dapat dinyatakan bahwa nilai DW adalah 1,950. Hasil Uji Durbin Watson menyatakan bahwa nilai DW terletak diantara nilai DU dan nilai 4 - DU, dan model analisis dinyatakan terbebas dari autokorelasi.

Setelah melakukan uji asumsi klasik, langkah selanjutnya yang dilakukan adalah menetapkan persamaan regresi sesuai dengan data analisis yang digunakan. Persamaan model regresi berganda moderasi dapat dinyatakan pada persamaan sebagai berikut:

$$
y=a+b_{1} \cdot x_{1}+b_{2} \cdot x_{2}+b_{3} \cdot z_{1}+b_{4} \cdot x_{1} \cdot z_{1}+b_{5} \cdot x_{2} . z_{1}+\varepsilon
$$

Keterangan:

$$
\begin{array}{ll}
\mathrm{y} & =\text { Harga Saham } \\
\mathrm{x}_{1} & =\text { Corporate Social Responsibility } \\
\mathrm{x}_{2} & =\text { Leverage } \\
\mathrm{Z}_{1} & =\text { Profitabilitas } \\
\mathrm{x}_{1} \cdot \mathrm{z}_{1} & =\text { Interaksi antara Corporate Social Responsibility dengan profitabilitas } \\
\mathrm{x}_{2} \cdot \mathrm{z}_{1} & =\text { Interaksi antara leverage } \text { dengan profitabilitas } \\
\mathrm{a} & =\text { Nilai konstanta regresi } \\
\mathrm{b}_{1} \cdot \mathrm{b}_{5} & =\text { Koefisien regresi } \\
\varepsilon & =\text { Random error }
\end{array}
$$

Tabel 3.

Output Koefisien Regresi

\begin{tabular}{ccc}
\hline Model & B & Std. Error \\
\hline (Constant) & $1.370,644$ & 488,400 \\
$\mathrm{X}_{1}$ & $2.497,228$ & $2.423,019$ \\
$\mathrm{X}_{2}$ & 14,719 & 197,402 \\
$\mathrm{Z}_{1}$ & $19.807,086$ & $4.143,060$ \\
$\mathrm{X}_{1} \mathrm{Z}_{1}$ & $10.963,620$ & $5.515,857$
\end{tabular}




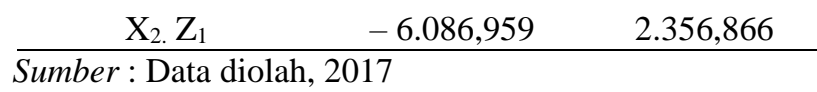

Berdasarkan Tabel 3. maka diperoleh persamaan regresi:

$$
\begin{aligned}
\mathrm{y}= & 1.370,644+2.497,228 . \mathrm{x}_{1}+14,719 . \mathrm{x}_{2}+19.807,086 . \mathrm{x}_{1} \\
& \left.+10.963,620 . \mathrm{x}_{1} \cdot \mathrm{x}_{1}-6.086,959 . \mathrm{x}_{2} . \mathrm{x}_{1} \ldots \ldots \ldots \ldots \ldots \ldots \ldots \ldots . .5\right)
\end{aligned}
$$

\section{Uji Hipotesis}

Uji F bertujuan untuk mengetahui model dalam kondisi fit. Uji F dilakukan dengan melihat nilai signifikansi $\mathrm{F}$ dengan level signifikansi 0,05. Hasil output menunjukkan bahwa signifikansi uji F yaitu sebesar 0,000. Hasil uji F menyatakan nilai signifikansi lebih kecil dari 0,05 . Hasil analisis menyatakan bahwa model regresi dalam kondisi fit. Apabila model regresi dinyatakan dalam kondisi fit, artinya model dalam kondisi layak uji dan baik. Analisis uji F didasarkan pada hasil olah data.

Tabel 4.

Output Signifikansi Uji t

\begin{tabular}{cccc}
\hline Variabel Bebas & t hitung & Sig. t & Keterangan \\
\hline $\mathrm{X}_{1}$ & 1,031 & 0,305 & Hipotesis ditolak \\
$\mathrm{X}_{2}$ & 0,075 & 0,941 & Hipotesis ditolak \\
$\mathrm{Z}_{1}$ & 4,781 & 0,000 & Hipotesis diterima \\
$\mathrm{X}_{1} . \mathrm{Z}_{1}$ & 1,988 & 0,049 & Hipotesis diterima \\
$\mathrm{X}_{2 .} \mathrm{Z}_{1}$ & $-2,583$ & 0,011 & Hipotesis diterima \\
\hline
\end{tabular}

Sumber : Data diolah, 2017

Uji t dilakukan untuk menyatakan pengaruh satu variabel independen secara individual dalam menerangkan variasi variabel dependen. Berdasarkan Tabel 4. hasil analisis dapat di interpretasikan sebagai berikut:

1) Variabel Corporate Social Responsibility $\left(\mathrm{X}_{1}\right)$ secara positif mempengaruhi harga saham (Y) tetapi nilai signifikansi lebih dari 0,05 yaitu 0,305. Pada hasil ini hipotesis dinyatakan ditolak karena tidak sesuai dengan hasil analisis yang diperoleh. Kedua hubungan menunjukkan hasil yang tidak signifikan. 
2) Variabel leverage $\left(\mathrm{X}_{2}\right)$ secara positif mempengaruhi harga saham $(\mathrm{Y})$ tetapi nilai signifikansi lebih dari 0,05 yaitu 0,941 . Hipotesis dinyatakan ditolak karena tidak sesuai dengan hasil analisis yang diperoleh. Kedua hubungan menunjukkan hasil yang tidak signifikan.

3) Variabel profitabilitas $\left(\mathrm{Z}_{1}\right)$ secara positif dan signifikan mempengaruhi harga saham (Y) karena nilai signifikansi tidak lebih dari 0,05 yaitu 0,000 . Profitabilitas yang tinggi secara signifikan dapat meningkatkan harga saham. Kondisi perusahaan dengan profit yang tinggi tentunya akan menjadi pertimbangan investor untuk berinvestasi. Hipotesis dinyatakan diterima karena sesuai dengan hasil analisis yang diperoleh.

4) Corporate Social Responsibility $\left(\mathrm{X}_{1}\right)$ dengan profitabilitas $\left(\mathrm{Z}_{1}\right)$ secara positif mampu mempengaruhi harga saham (Y) karena signifikansi kurang dari 0,05 yaitu 0,049. Koefisien interaksi Corporate Social Responsibility $\left(\mathrm{X}_{1}\right)$ dengan profitabilitas $\left(\mathrm{Z}_{1}\right)$ yang bernilai positif menunjukkan profit yang tinggi dengan diimbangi dengan pelaksanaan Corporate Social Responsibility dapat meningkatkan harga saham yang disebabkan oleh pengungkapan Corporate Social Responsibility. Hipotesis dinyatakan diterima karena sesuai dengan hasil analisis yang diperoleh dan profitabilitas dinyatakan dapat memperkuat hubungan keduanya.

5) Leverage $\left(\mathrm{X}_{2}\right)$ dengan profitabilitas $\left(\mathrm{Z}_{1}\right)$ secara negatif dan signifikan mempengaruhi harga saham (Y) karena signifikansi kurang dari 0,05 yaitu 0,011. Koefisien interaksi leverage $\left(\mathrm{X}_{2}\right)$ dengan profitabilitas $\left(\mathrm{Z}_{1}\right)$ yang bernilai negatif menunjukkan bahwa penggunaan leverage yang semakin tinggi dengan 
diimbangi dengan profit yang tinggi mampu mengurangi penurunan harga saham yang disebabkan oleh leverage. Hipotesis dinyatakan diterima karena sesuai dengan hasil analisis yang diperoleh dan profitabilitas dinyatakan dapat memperkuat hubungan keduanya.

\section{Koefisien Determinasi}

Uji koefisien determinasi untuk mengukur sumbangan yang diberikan variabel bebas terhadap variabel terikat. Hasil analisis menyatakan bahwa nilai $R$ square yaitu sebasar 0,254 yang menandakan bahwa 25,4\% perubahan harga saham disebabkan oleh Corporate Social Responsibility, leverage, profitabilitas, interaksi antara Corporate Social Responsibility dan profitabilitas, dan interaksi antara leverage dan profitabilitas. Hasil $R$-square pada penelitian ini menunjukkan nilai pengaruh yang cukup kecil antar variabel yang diteliti.

\section{Pembahasan}

\section{1) Pengaruh Pengungkapan Corporate Social Responsibility Terhadap Harga Saham}

Hasil analisis menyatakan pengungkapan Corporate Social Responsibility secara tidak signifikan mempengaruhi harga saham. Hasil ini tidak sesuai dengan penyusunan hipotesis yang ditetapkan. Konsep Corporate Social Responsibility memerlukan biaya yang ditentukan melalui kebijakan pendanaan perusahaan. Biaya-biaya harus di dasarkan pada pilihan manajemen berdasarkan pada keseimbangan biaya marjinal dan pendapatan marjinal (Vitaliano and Stella, 2006).

Secara teoritis konsep Corporate Social Responsibility berpegang pada tiga hal penting yaitu people, planet, profit. Pada faktanya pelaksanaan Corporate 
Social Responsibility memerlukan pendanaan khusus dari perusahaan. Kegiatankegiatan yang tercakup didalamnya memerlukan kebijakan pendanaan sendiri yang harus ditentukan oleh perusahaan. Salah satu pendanaan yang digunakan sebagai sumber pelaksanaan Corporate Social Responsibility adalah berasal dari profit perusahaan. Tanpa adanya profit yang seimbang, tentunya pelaksanaan Corporate Social Responsibility tidak dapat terjadi. Kondisi ini tentunya secara tidak langsung menyatakan bahwa memang benar Corporate Social Responsibility tidak bisa secara langsung mempengaruhi harga saham.

Data Corporate Social Responsibility didata laporan tahunan perusahaan yang digunakan sebagai sampel memiliki rasio pengungkapan yang sangat kecil. Data penelitian juga menunjukkan bahwa perusahaan sampel lebih cenderung melakukan pengungkapan pada kelompok indikator sosial dan ekonomi, tetapi pengungkapan pada indikator lingkungannya sangat kecil. Kecilnya rasio pengungkapan menjadi salah satu penyebab tidak terjadinya pengaruh signifikan antara Corporate Social Responsibility dengan harga saham.

\section{2) Pengaruh Leverage Terhadap Harga Saham}

Hasil analisis menyatakan hubungan yang tidak signifikan antara leverage terhadap harga saham. Penggunaan leverage yang tinggi tentunya tidak dapat mempengaruhi harga saham. DER menunjukkan setiap modal sendiri yang digunakan sebagai jaminan hutang. Berdasarkan pada pecking order theory, jika perusahaan membutuhkan pendanaan, perusahaan dapat memilih sumber pendanaan dari hutang karena lebih aman dari ekuitas (Amirya dan Atmini, 2008). Faktor yang mempengaruhi harga saham adalah proporsi hutang perusahaan 
terhadap ekuitas (Kusumawardani, 2010). Para investor akan cenderung tidak memilih perusahaan dengan tingkat leverage yang tinggi sebagai tempat berinvestasi.

Rasio leverage yang tinggi menyebabkan para investor lebih mempertimbangkan keputusan investasinya. Rasio leverage yang tinggi dianggap sebagai suatu risiko yang dihindari oleh investor (Rusliati dan Prasetyo, 2011). Semakin tinggi hutang yang ditanggung perusahaan maka semakin menurun kemampuan modal perusahaan untuk menutupi hutangnya, sehingga menyebabkan harga saham menurun (Wilianto, 2012). Sehingga perusahaan memerlukan komponen lain untuk dapat meningkatkan harga saham diimbangi dengan penggunaan leverage yang tinggi, salah satunya adalah profit.

\section{3) Pengaruh Profitabilitas Terhadap Harga Saham}

Hasil analisis data menyatakan bahwa profitabilitas secara signifikan mampu mempengaruhi harga saham. Perlu diketahui bahwa profitabilitas merupakan rasio keuangan yang dapat digunakan oleh perusahaan untuk mengukur kemampuannya dalam proses memperoleh laba. Semakin banyak investor yang berinvestasi maka secara langsung akan mempengaruhi harga saham perusahaan. Semakin tinggi rasio ROE maka semakin tinggi juga tingkat keuntungan (Agustina, 2013).

Peningkatan laba yang digambarkan pada tingginya ROE dapat meningkatkan minat investor untuk membeli saham (Polli, dkk., 2014). Ketika ROE menjadi tinggi maka secara tidak langsung harga saham juga ikut meningkat (Rinati, 2009). Tingginya rasio Profitabilitas dianggap sebagai kesempatan baik 
untuk para investor. Tidak bisa dipungkiri bahwa salah satu tujuan investor berinvestasi adalah untuk mendapatkan profit.

\section{4) Pengaruh Pengungkapan Corporate Social Responsibility Terhadap Harga Saham dengan Profitabilitas sebagai Pemoderasi}

Salah satu komponen yang dapat digunakan sebagai pemoderasi adalah profitabilitas. Kedudukan profitabilitas disini dapat memperkuat maupun memperlemah hubungan kedua variabel. Hasil analisis menyatakan bahwa profitabilitas secara signifikan dapat memoderasi hubungan antara Corporate Social Responsibility dengan harga saham. Hasil analisis membuktikan bahwa profitabilitas mampu memperkuat hubungan antara Corporate Social Responsibility dengan harga saham.

Hasil analisis data sesuai dengan penyusunan hipotesis yang telah ditetapkan. Berdasarkan analisis data dapat diketahui bahwa dengan adanya tingkat profitabilitas yang tinggi maka perusahaan dapat melakukan Corporate Social Responsibility dengan baik. Semakin baik citra perusahaan maka secara tidak langsung dapat meningkatkan harga saham. Citra baik dapat meningkatkan kepercayaan mereka terhadap perusahaan. Tingginya rasa percaya dapat berpengaruh pada kesuksesan perusahaan dan tentunya dalam proses pencapaian profitabilitas yang maksimal (Kanwal et al., 2013).

Ketika perusahaan tidak memiliki profit yang cukup, tentunya perusahaan tidak dapat melakukan program Corporate Social Responsibility dengan baik. Kondisi ini yang menyebabkan Corporate Social Responsibility tidak bisa secara langsung mempengaruhi harga saham. Tujuan dari pengungkapan Corporate Social 
Responsibility salah satunya adalah sebagai strategi perusahaan untuk meningkatkan citra perusahaan.

Peloza (2009) menyatakan bahwa terjadi pengaruh positif antara kinerja keuangan dengan pelaksanaan Corporate Social Responsibility baik secara sosial dan lingkungan. Polli, dkk (2014) melakukan pengujian dengan menggunakan variabel ROE dan harga saham. Hasil penelitian mengatakan ROE berpengaruh signifikan terhadap harga saham. Anggraini (2006) menyatakan bahwa profitabilitas dapat memperkuat pengaruh Corporate Social Responsibility terhadap nilai perusahaan. Salah satu indikator penting dalam nilai perusahaan adalah ditentukan melalui harga saham perusahaan.

\section{5) Pengaruh Leverage Terhadap Harga Saham dengan Profitabilitas sebagai Pemoderasi}

Hasil penelitian menyatakan profitabilitas secara signifikan mampu memoderasi hubungan antara leverage dengan harga saham. Hasil ini sesuai dengan penyusunan hipotesis yang telah ditetapkan. Berdasarkan hasil pengujian hipotesis sebelumnya diperoleh bahwa leverage secara tidak signifikan berpengaruh terhadap harga saham. Salah satu penyebabkan karena semakin tinggi hutang dianggap sebagai risiko investasi oleh para investor. Sehingga harga saham tidak dapat dipengaruhi oleh hutang yang tinggi.

Penggunaan moderasi diperlukan untuk mengetahui hubungan keduanya. Salah satu komponen yang dapat digunakan sebagai pemoderasi adalah profitabilitas. Penggunaan leverage yang tinggi diimbangi dengan profit yang tinggi tentunya dapat menurunkan risiko penurunan harga saham yang disebabkan oleh leverage itu sendiri. Ketika perusahaan memilih menggunakan menggunakan 
leverage yang tinggi dengan diimbangi dengan profit yang tinggi, tentunya para investor juga akan memperhatikan profit.

Hasil penelitian ini sejalan dengan penelitian Ariyanti, dkk (2016), Mahmud (2014), dan Kusumawardani (2010) melakukan penelitian dengan mengukur leverage melalui rasio DR dan DER terhadap harga saham. Hasil penelitian menyatakan leverage memiliki hubungan signifikan terhadap harga saham. Polli, dkk (2014) menyatakan ROE berpengaruh signifikan terhadap harga saham. Hasil yang sama juga diperoleh pada penelitian Sondakh, dkk (2015), Manoppo (2015), dan Rinati (2009). Hasil penelitian Putriana (2016) juga menunjukkan ROE mampu memoderasi hubungan DER dengan harga saham.

\section{SIMPULAN DAN SARAN}

Kesimpulan penelitian ini yaitu, pertama, Corporate Social Responsibility berpengaruh tidak signifikan terhadap harga saham. Kecilnya rasio pengungkapan menjadi salah satu penyebab tidak terjadinya pengaruh signifikan antara Corporate Social Responsibility dengan harga saham. Kedua, leverage berpengaruh tidak signifikan dengan harga saham. Semakin tinggi hutang yang ditanggung perusahaan maka semakin menurun kemampuan modal perusahaan untuk menutupi hutangnya, sehingga menyebabkan harga saham menurun.

Ketiga, profitabilitas berpengaruh signifikan dengan harga saham. Semakin tinggi profit yang diperoleh perusahaan maka akan semakin tertarik investor untuk berinvestasi. Keempat, profitabilitas secara signifikan mampu memoderasi pengaruh antara Corporate Social Responsibility dan harga saham. Hasil membuktikan bahwa profitabilitas mampu memperkuat hubungan keduanya. 
Kelima, profitabilitas secara signifikan mampu memoderasi pengaruh antara leverage terhadap harga saham. Hasil membuktikan bahwa profitabilitas mampu memperkuat hubungan antara leverage dan harga saham.

Beberapa saran yang dapat diberikan khususnya kepada para emiten perusahaan, para investor dan para peneliti selanjutnya. Saran penelitian dapat dijadikan sebagai salah satu bahan pertimbangan untuk pengambilan keputusan yang masih berhubungan dengan variabel yang diteliti. Penyusunan saran dilakukan berdasarkan pada hasil analisis data penelitian serta fenomena yang terbentuk dari telaah pustaka dan penelitian sebelumnya.

Saran pertama kepada emiten perusahaan, berdasarkan pada data yang digunakan, tingkat pengungkapan Corporate Social Responsibility khususnya pada perusahaan sampel memiliki rasio rata-rata yang cukup kecil. Kecilnya tingkat pengungkapan Corporate Social Responsibility ini menyebabkan Corporate Social Responsibility tidak memiliki pengaruh yang cukup besar pada perusahaan, apalabi dalam hal mempengaruhi harga saham.

Berdasarkan hal itu diharapkan perusahaan dapat melaksanakan Corporate Social Responsibility dengan lebih baik lagi terutama dibidang lingkungan untuk menciptakan citra perusahaan yang lebih baik. Penggunaan tingkat leverage yang tinggi dapat dijadikan perusahaan sebagai komponen dasar dalam meningkatkan profit. Hal tersebut dapat digunakan sebagai strategi dalam meningkatkan minat investor yang salah satunya dapat meningkatkan harga saham.

Kedua kepada Investor, hubungan yang dibahas antara Corporate Social Responsibility dan leverage dengan harga saham dapat dijadikan investor untuk 
sebuah pertimbangan. Tingkat hutang yang tinggi akan dianggap sebagai sebuah resiko oleh investor, tetap jika diimbangi dengan profit yang tinggi maka akan mampu menurunkan resiko penurunan saham yang disebabkan oleh hutang itu sendiri. Pengungkapan Corporate Social Responsibility dapat dijadikan sebuah kebijakan oleh pemerintah untuk menciptakan citra baik pada perusahaan.

Citra perusahaan yang baik dapat dijadikan oleh investor sebagai salah satu pertimbangan dalam proses investasi. Semakin baik citra suatu perusahaan maka akan semakin tercermin dengan baik nilai perusahaannya. Kebijakan yang diambil perusahaan serta sistem-sistem yang diterapkan juga tercermin dari baik atau tidaknya citra sebuah perusahaan. Oleh karena itu para investor sebaiknya juga mempertimbangkan citra perusahaan dalam keputusan berinvestasi.

Ketiga kepada peneliti selanjutnya, hasil penelitian menyatakan bahwa nilai koefisien determinasi yang kecil. Kecilnya nilai tersebut menggambarkan bahwa hubungan antar variabel pengaruhnya sangat kecil. Ketika pengaruhnya sangat kecil maka diperlukan variabel lain yang lebih cocok untuk diuji. Sehingga diperlukan pengujian dengan menggunakan variabel independen atau variabel moderasi lainnya untuk mengetahui penyebab perubahan harga saham. Pemilihan variabel juga harus didasarkan pada fenomena yang terjadi secara riil pada kondisi perusahaan sampel yang dipilih.

\section{IMPLIKASI PENELITIAN}

Hasil penelitian memberikan hasil yang tidak signifikan pada hubungan langsung antara Corporate Social Responsibility dan harga saham maupun leverage dan harga saham. Hasil ini menandakan bahwa kedua hubungan memerlukan 
komponen pembantu yang mampu memperkuat maupun memperlemah keduanya, sehingga hubungan Corporate Social Responsibility dan harga saham dapat terlihat secara transparan. Hasil penelitian menunjukkan bahwa kedua hubungan mampu memperoleh hasil signifikan dengan profitabilitas sebagai pemoderasi. Hasil tersebut membuktikan bahwa posisi profit dapat memperkuat hubungan keduanya.

Peran profit dalam penelitian ini sangat besar, karena dengan adanya profit hubungan antar variabel dapat menjadi signifikan. Hasil ini menandakan bahwa kedudukan profit pada suatu perusahaan sangatlah penting. Ketika perusahaan ingin mendapatkan harga saham yang baik, maka perusahaan harus bisa mencapai profit yang maksimal. Pencapaian profit yang maksimal akan berhubungan dengan kesejahteraan para investor.

Pada penelitian ini terdapat beberapa keterbatasan yang dapat disempurnakan lagi kearah yang lebih baik oleh peneliti selanjutnya. Sebaiknya dilakukan penelitian dengan menggunakan variabel moderasi lainnya. Pada penelitian lainnya maka dapat diketahui variabel apa saja lagi yang dapat memoderasi hubungan keduanya. Kedudukan profit yang sangat penting dapat dijadikan pertimbangan untuk menguji variabel lain untuk dijadikan sebagai variabel moderasi.

Rasio Corporate Social Responsibility sangat kecil pada hasil penelitian ini dapat dijadikan pertimbangan untuk para peneliti selanjutnya. Kecilnya rasio pengungkapan menjadi salah satu penyebab pengaruh yang diberikan pada hubungan antara Corporate Social Responsibility dan harga saham menjadi tidak signifikan. Pada penelitian selanjutnya dapat dilakukan juga penelitian dengan 
menggunakan periode penelitian yang lebih panjang dari satu tahun untuk dapat membandingkan hasil analisis setiap tahun yang diperoleh.

\section{REFERENSI}

Anggraini, Fr. Reni Retno. 2006. Pengungkapan Informasi Sosial dan Faktor-faktor yang Mempengaruhi Pengungkapan Informasi Sosial dalam Laporan Keuangan Tahunan, Artikel Penelitian, Simposium Nasional Akuntansi IX, Padang, 23-26 Agustus.

Agustina, Silvia. 2013. Pengaruh Profit dan Pengungkapan Corporate Social Responsibility Terhadap Nilai Perusahaan (Studi Empiris pada Perusahaan Manufaktur yang Terdaftar di Bursa Efek Indonesia), Artikel Penelitian, Program Studi Akuntansi Fakultas Ekonomi Universitas Negeri Padang.

Anwar, A., Haerani, S., dan Pagalung, G. 2010. Pengungkapan Corporate Social Responsibility terhadap Kinerja Keuangan Perusahaan dan Harga Saham. Journal of Academia, pp. 1-8.

Amirya, M. dan Atmini, S. 2008. Determinan Tingkat Hutang Serta Hubungan Tingkat Hutang Terhadap Nilai Perusahaan: Perspektif Pecking Order Theory. Jurnal Akuntansi dan Keuangan Indonesia, Vol. 5, No. 2, pp. 227244.

Ariyanti, S. Topowijono, dan Sulasmiyati, S. 2016. Pengaruh Profitabilitas dan Leverage terhadap Harga Saham (Studi pada Perusahaan Kontruksi dan Bangunan yang Terdaftar di Bursa Efek Indonesia Periode 2011-2014). Jurnal Administrasi Bisnis (JAB), Vol. 35, No. 2, pp. 181-188.

Babalola, Y.A. 2012. The Impact of Corporate Social Responsibility on Firm's Profitability in Nigeria. European Journal of Economics, Finance and Administrative Sciences, Issue 45, pp. 39-49.

Boaventura, G.M.J, Da Silva, S.R., dan Bandeira-de-Mello, R. 2012. Corporate Financial Performance and Corporate Social Performance: Methodological Development and the Theoretical Contribution of Empirical Studies*. Journal of USP, São Paulo, Vol. 23, No. 60, pp. 232-245. 
Carroll, B.A. dan Shabana, M.K. 2010. The Business Case for Corporate Social Responsibility: A Review of Concepts, Research and Practice. International Journal of Management Reviews, pp. 85-105.

Edmawati, D.S. 2012. Pengungkapan Informasi Tanggung Jawab Sosial Perusahaan dan Pengaruhnya Terhadap Nilai Perusahaan dengan Profitabilitas Sebagai Variabel Moderating (Studi Empiris pada Perusahaan Manufaktur yang Terdaftar di Bursa Efek Indonesia). Jurnal Manajemen dan Kewirausahaan, Vol. 3, No. 3, pp. 74-95.

Handriyani, N.A. 2013. Pengaruh Corporate Social Responsibility Terhadap Nilai Perusahaan dengan Profitabilitas Sebagai Variabel Moderating. Jurnal Ilmu dan Riset Akutansi, Vol. 2, No.5, pp. 1-15.

Hamdani, M. 2014. Hubungan Pengungkapan Corporate Social Responsibility (CSR) terhadap Kinerja Keuangan dan Harga Saham pada Perusahaan LQ45. Jurnal Organisasi dan Manajemen, Vol. 10, No. 1, pp. 27-36.

Hidayansyah, P.F., Hubeis, M. and Irwanto, A.K., 2015. Pengaruh Pengungkapan Corporate Social Responsibility terhadap Kinerja Keuangan dan Harga Saham pada Sektor Properti di Bursa Efek Indonesia. Jurnal Manajemen dan Organisasi, Vol. 6, No. 1, pp. 74-89.

Iqbal, N., Ahmad, N., Basheer, A.N., and Nadeem, M. 2012. Impact of Corporate Social Responsibility on Financial Performance of Corporation: Evidence from Pakistan. International Journal of Learning \& Development, Vol. 2, No. 6, pp. 107-118.

Kanwal, H., Khanam, F., Nasreen, S., and Hameed, S. 2013. Impact of Corporate Social Responsibility on the Firm's Financial Performance. IOSR Journal of Business and Management (IOSR-JBM), Vol. 14, Issue 5, pp 67-74.

Kiran, S., Kakakhel, J.S., dan Shaheen, F. 2015. Corporate Social Responsibility and Firm Profitability: A Case Of Oil and Gas Sector of Pakistan. Journal of City University Research, Vol. 5, No. 1, pp. 110-119.

Kusumawardani, A. 2010. Analisis Pengaruh EPS, PER, ROE, FL, DER, CR, ROA pada Harga Saham dan Dampaknya terhadap Kinerja Perusahaan LQ45 yang Terdaftar di BEI Periode 2005-2009. Jurnal Universitas Gunadarma, pp. 117. 
Lee, S. dan Park, S.Y. 2010. Financial Impacts of Socially Responsible Activities on Airline Companies. Journal of Hospitality \& Tourism Research, Vol. 34, No. 2, pp. 185-203.

Lech, A. 2013. Corporate Social Responsibility and Financial Performance, Theoretical and Empirical Aspects. Journal of Versita, Vol. 10, pp. 49-62.

Luhukay, R., Mangantar, M., dam Baramuli, D. Analisis Pengaruh Kinerja Keuangan terhadap Harga Saham pada Perusahaan Rokok yang Terdaftar di Bursa Efek Indonesia. Jurnal EMBA, Vol. 5, No. 5, pp. 501-510.

Mahmud, F., Nani, S., dan Ishak, Masri I. 2014. Pengaruh Financial Leverage terhadap Harga Saham pada PT Unilever Indonesia Tbk. Periode Penelitian 2003-2012, Artikel, Jurusan Manajemen, Fakultas Ekonomi dan Bisnis, Universitas Negeri Gorontalo.

Manoppo, P. C. 2015. Pengaruh ROA, ROE, ROS, dan EPS terhadap Harga Saham. Jurnal EMBA, Vol. 3, No. 4, pp. 691-697.

Mukhtaruddin, Y., Relasari, Soebyakto, B.B., Irham, R. and Abukosim. 2014. Earning Management, Corporate Social Responsibility Disclosures and Firm's Value: Empirical Study on Manufacturing Listed on IDX Period 20102012. Net Journal of Business Management, Vol. 2, No. 3, pp. 48-56.

Nurlela, R. dan Islahudin. 2008. Pengaruh Corporate Social Responsibility terhadap Nilai Perusahaan dengan Prosentase Kepemilikan Manajemen sebagai Variabel Moderating, Artikel Penelitian, Simposium Nasional Akuntansi XI, pp. 1-25.

Peloza, J. 2009. The Challenge of Measuring Financial Impacts from Investments in Corporate Social Performance. Journal of Management, Vol. 35, No. 6, pp. 1518-1541.

Putri, Anizza G. 2013. Pengaruh Pengungkapan Corporate Social Responsibility terhadap Harga Saham (Studi Empiris pada Perusahaan Pertambangan yang Terdaftar di Bursa Efek Indonesia Periode 2009-2011), Skripsi, Universitas Negeri Yogyakarta, Yogyakarta. 
Putriana. 2016. Pengaruh Leverage (Debt to Equity Ratio) dan Likuiditas (Current Ratio) terhadap Harga Saham dengan Profitabilitas (Return On Equity) sebagai Variabel Moderating, Skripsi, Universitas Sultan Ageng Tirtayasa, Banten.

Polli, P. J. V. Saerang, I., dan Mandagie, Y. 2014. Rasio Keuangan Pengaruhnya terhadap Harga Saham pada Bank Umum Swasta Nasional Devisa yang Go Public di Bursa Efek Indonesia. Jurnal EMBA, Vol. 2. No. 2. pp. 993-1004.

Pratomo, M. 2010. Analisis Pengaruh Pengungkapan Informasi Corporate Social Responsibility (CSR) terhadap Harga Saham Perusahaan (Studi Peristiwa Saham LQ45 Periode Agustus 2007-Februari 2008), Artikel, Universitas Sanata Dharma, Yogyakarta.

Rusliati, E. dan Prasetyo, G. 2011. Pengaruh Financial Leverage, Earnings per Share, dan Dividend per Share terhadap Harga Saham. Jurnal Trikonomika, Vol. 10, No. 1, pp. 31-39.

Rinati, I. 2009. Pengaruh Net Profit Margin (NPM), Return on Assets (ROA) dan Return on Equity (ROE) terhadap Harga Saham pada Perusahaan yang Tercantum dalam Indeks LQ45. Jurnal Jurusan Akuntansi Universitas Gunadarma, pp. 1-12.

Rosiliana, K., Yuniarta, A.G., dan Darmawan, S.A.N. 2014. Pengaruh Corporate Social Responsibility Terhadap Kinerja Keuangan Perusahaan (Studi Empiris Pada Perusahaan LQ45 di Bursa Efek Indonesia Periode 2008-2012). Jurnal Jurusan Akutansi Universitas Pendidikan Ganesha, Vol. 02, No. 1, pp. 1-13.

Sondakh, F., Tommy, P., dan Mangantar, M. 2014. Current Ratio, Debt to Equity Ratio, Return on Asset, Return on Equity Pengaruhnya terhadap Harga Saham pada Indeks LQ 45 di BEI Periode 2010-2014. Jurnal EMBA, Vol. 3, No. 2, pp. 749-756.

Tahalele, E. J. S. dan Mekel, A. P. 2014. The Analysis of Leverage in Indonesia's Food and Beverage Processing Companies to Their Profitability. Jurnal EMBA, Vol. 2, No. 3, pp. 477-487.

Undang-undang Republik Indonesia Nomor 40 Tahun 2007 tentang Perseroan Terbatas. 
AA Dewi Hendrayani, Ni Luh Putu Wiagustini, dan I B Panji Sedana. Pengaruh Pengungkapan.....

Vitaliano, F.D. and Stella, P.G. 2006. The Cost of Corporate Social Responsibility: The Case of Community Reinvestment Act. Journal of J Prod Anal Springer, Vol. 2, No. 6, pp. 235-244.

Wilianto, A. 2012. Pengaruh Kebijakan Dividen, Leverage Keuangan dan Profitabilitas terhadap Harga Saham Perusahaan Manufaktur di BEI. Jurnal Ilmiah Mahasiswa Akuntansi, Vol. 1, No.2, pp. 33-37.

Yaparto, M., Frisko K, D., dan Eriandani, R. 2013. Pengaruh Corporate Social Responsibility Terhadap Kinerja Keuangan Pada Sektor Manufaktur yang Terdaftar di Bursa Efek Indonesia pada Periode 2010-2011. Jurnal Ilmiah Mahasiswa Universitas Surabaya, Vol.2, No.1, pp. 1-19. 